\title{
The impact of zebra mussel (Dreissena polymorpha) periostracum and biofilm cues on habitat selection by a Ponto-Caspian amphipod Dikerogammarus haemobaphes
}

\author{
Jarosław Kobak • Tomasz Kakareko • \\ Łukasz Jermacz • Małgorzata Poznańska
}

Received: 30 May 2012/Revised: 31 August 2012/Accepted: 10 September 2012/Published online: 23 September 2012

(C) The Author(s) 2012. This article is published with open access at Springerlink.com

\begin{abstract}
Dikerogammarus haemobaphes is one of several Ponto-Caspian gammarids invading Europe in recent decades. Previously, it exhibited active preferences for habitats associated with another Ponto-Caspian alien, zebra mussel. Now we tested gammarid preferences for living mussels and their empty shells with biofilm and/or periostracum present or absent, to find the exact cues driving gammarid responses. We observed a strong preference of gammarids for biofilmed shells, even if the biofilm was relatively young (2-day old). However, the biofilm quality, related to the substratum on which it had developed (shells with or without the periostracum, or coated with nail varnish) did not affect their behaviour. In the absence of biofilm, gammarids positively responded to the shell periostracum. Furthermore, they clearly preferred living zebra mussels over old empty shells, independent of
\end{abstract}

Handling editor: Chris Joyce

\section{Present Address:}

J. Kobak $(\bowtie) \cdot$ Ł. Jermacz · M. Poznańska

Department of Invertebrate Zoology, Faculty of Biology and Environmental Protection, Nicolaus Copernicus University, Toruń, Poland

e-mail: jkob73@umk.pl

T. Kakareko $\cdot$ Ł. Jermacz

Department of Hydrobiology, Faculty of Biology and Environmental Protection, Nicolaus Copernicus University, Toruń, Poland the presence or absence of biofilm, confirming the importance of a periostracum-associated cue in their substratum recognition. On the other hand, shells obtained shortly after mussels' death were preferred over living bivalves. Thus, the attractant is associated with fresh mussel shells, rather than with living mussels themselves. The ability of alien gammarids to locate sites inhabited by zebra mussels may contribute to their invasion success in novel areas inhabited by this habitat-forming bivalve.

Keywords Behaviour - Habitat preferences · Interspecific interactions - Shell habitat - Invasional meltdown hypothesis - Invasive species

\section{Introduction}

Several species of Ponto-Caspian amphipods, including Dikerogammarus haemobaphes (Eichwald, 1841), D. villosus (Sowinsky, 1894), Pontogammarus robustoides (G. O. Sars, 1894) and Chaetogammarus ischnus (Stebbing, 1899), appeared in European inland waters in the twentieth century (bij de Vaate et al., 2002; Jażdżewski et al., 2002; Konopacka, 2004). Due to their gregariousness and omnivorous feeding habits with strong inclinations for predation, they considerably affect local communities, changing their abundances and taxonomic composition (MacNeil et al., 1997; Berezina \& Panov, 2003; Devin et al., 2003). In particular, they exclude native gammarid populations 
from their preferred habitats by intraguild predation, intraspecific competition and indirect impact on food webs (Arbaciauskas, 2002; Berezina \& Panov, 2003; Kley \& Maier, 2006; van Riel et al., 2007; MacNeil et al., 2011).

Tolerance to a wide range of abiotic factors, especially salinity, as well as fast reproduction and a predatory nature contribute to the invasion success of the Ponto-Caspian gammarids (Devin \& Beisel, 2007; Grabowski et al., 2007). Moreover, these highly mobile animals are capable of accurate selection of optimum microhabitats with suitable shelters and food resources (Boets et al., 2010; Czarnecka et al., 2010). Biotic factors are also important for their invasive potential. Alien organisms in novel areas become involved in multiple interspecific interactions, including those with other invaders (Simberloff \& von Holle, 1999; Ricciardi, 2001). Ricciardi (2001) demonstrated that the number of positive interactions between alien species might exceed the number of negative relationships, thus contributing to their invasion success. This supports the invasional meltdown hypothesis, stating that an ecosystem becomes more susceptible to new biological invasions with the increasing number of previous successful invaders (Simberloff \& von Holle, 1999).

In newly colonized areas, gammarids often meet another Ponto-Caspian alien, zebra mussel Dreissena polymorpha (Pallas, 1771). This bivalve started its invasion in Europe at the beginning of nineteenth century and since then has spread to most European countries, as well as to a considerable part of North America. It is regarded as an extremely efficient ecosystem engineer (Karatayev et al., 2002). Mussels form large colonies providing shelters for benthic organisms and produce food (faeces and pseudofaeces) for detritivores (Wolnomiejski, 1970; Botts et al., 1996; Ricciardi et al., 1997). Mussels themselves are valuable food for molluscivores (Karatayev et al., 2001). Thus, most benthic taxa increase their abundances in mussel colonies. In turn, invertebrate predators benefit from the increased number of their benthic prey in mussel colonies and also increase in numbers (Botts et al., 1996; Ricciardi et al., 1997). Zebra mussels have been assumed to promote the spread of several species of fish, including the molluscivorous round goby Neogobius melanostomus (Pallas, 1814) and benthivorous ruffe Gymnocephalus cernua (Linnaeus, 1758) in North America by providing them with suitable food, as well as a hydroid
Cordylophora caspia (Pallas, 1771), benefiting from a food source (mussel veligers) and additional hard substratum (Ricciardi, 2001). Therefore, this bivalve is often used as a model example supporting the meltdown hypothesis (Simberloff \& Von Holle, 1999). On the other hand, a growing body of evidence shows that native taxa, such as amphipods and ephemeropterans evolving allopatrically with zebra mussels, can benefit from the presence of mussel colonies to the same extent as aliens, thus questioning the role of dreissenids in the invasional meltdown (Kestrup \& Ricciardi, 2009; DeVanna et al., 2011).

Nevertheless, several species of Ponto-Caspian gammarids, such as C. ischnus, D. villosus and $D$. haemobaphes have been found in great densities among zebra mussels, which can help them colonize new areas (Devin et al., 2003; Gonzalez \& Burkart, 2004; Wawrzyniak-Wydrowska \& Gruszka, 2005; Żytkowicz et al., 2008). They exhibit apparent affinity for habitats formed by zebra mussels and select them preferentially in the presence of other substrata. Active preferences for mussels have been found in the taxa known for their associations with hard substrata: C. ischnus (Van Overdijk et al., 2003) and D. haemobaphes (Kobak \& Żytkowicz, 2007). Furthermore, another Ponto-Caspian species, D. villosus, was observed in high numbers among zebra mussel shells in the field (Devin et al., 2003; Boets et al., 2010) and showed active preferences for shells and living specimens of another invasive bivalve, Corbicula fluminea (O. F. Müller, 1774), in the laboratory (Werner \& Rothhaupt, 2008). Gammarids can benefit from the presence of zebra mussels by using their shells as shelters as well as utilizing food resources provided by bivalves, such as increased abundance of benthic prey, faeces and pseudofaeces (Gonzalez \& Burkart, 2004; Gergs \& Rothhaupt, 2008a). Moreover, gammarids living among mussel shells were found to affect their molluscan hosts by modifying their attachment to substratum and locomotion (Kobak et al., 2012) as well as biting their fresh byssal threads (Platvoet et al., 2009. This shows that relationships among these taxa are reciprocal, they respond to each other and adjust their behaviour accordingly.

Dikerogammarus haemobaphes was previously found to prefer empty mussel shells over musselshaped stones, as well as living bivalves over these two substratum types (Kobak \& Żytkowicz, 2007). In the 
present study, we intended to find the source of a cue attracting $D$. haemobaphes to living dreissenids and their shells. Previous research has shown that this cue is likely associated with the shell surface (Kobak \& Żytkowicz, 2007; Kobak et al., 2009), but its exact nature has not been determined. We hypothesized that two potential attractant sources were possible: (1) the biofilm developing on shells, which is possibly different from those growing on other surfaces and/or (2) the outer proteinaceous shell layer, the periostracum. To check which of these structures contain the attractant, we designed a series of pairwise choice experiments, in which D. haemobaphes was tested in the presence of living mussels and empty shells with their biofilm and/or periostracum layer absent or left intact. We hypothesized that the biofilm presence and quality, as well as the periostracum in itself could attract gammarids. Furthermore, we intended to check how biofilm age affects gammarid choice. We assumed that even young biofilms would attract gammarids, as they are usually among the first colonizers of artificial substrata deployed in water (Costello \& Myers, 1996).

\section{Materials and methods}

Animals

We collected Dikerogammarus haemobaphes individuals together with zebra mussel colonies by SCUBA diving in the Smukalski Reservoir (a reservoir on the River Brda near the city of Bydgoszcz, central Poland) from a depth of 3-4 m. We kept the mussels and gammarids in 100-200-1 tanks with settled, aerated tap water at room temperature (ca. $19-22^{\circ} \mathrm{C}$ ), under a natural photoperiod of August and September. We fed the gammarids living chironomid larvae and flake food for aquarium fish and used them within 1-2 weeks after collection. We confirmed the taxonomic position of the gammarids according to Konopacka (2004). Mean body length of the gammarids used in our study (based on a sample of 100 specimens randomly selected from all tested individuals) was $9.1 \mathrm{~mm}$ (range: $5.8-15.2 \mathrm{~mm}$ ).

\section{Substratum preparation}

We used tiles $(100 \times 100 \times 5 \mathrm{~mm})$ made of resocart (thermosetting plastic based on phenol-formaldehyde resin) as basic substrata. This material is suitable for the recruitment of epifauna (Kobak, 2005). To prepare various habitats, we glued empty mussel shells, living mussels or stones to the tiles ( 8 objects per tile) with fast-binding methyl acrylic glue, in the pattern shown in Fig. 1. The glue was applied to every object type in our study, so it could not affect the gammarid choice in our experiments. We cleaned the tiles and all the objects used in our study by gentle sanding to remove the remnants of attached byssal threads and debris particles.

We obtained empty shells from mussels that died naturally in the laboratory ca. 3-6 months before the present experiments, unless stated otherwise in the text. We glued their valves together using aquarium silicone glue to imitate a living mussel shape. The glue was only located inside the shells, so the tested gammarids had no direct contact with it.

We removed the periostracum from some shells by rinsing them for a few days in a sodium hypochlorite solution, adapting the method applied by Crisp (1967) and Tamburri et al. (1992). Because this chemical is highly toxic to aquatic organisms (Martin et al., 1992),

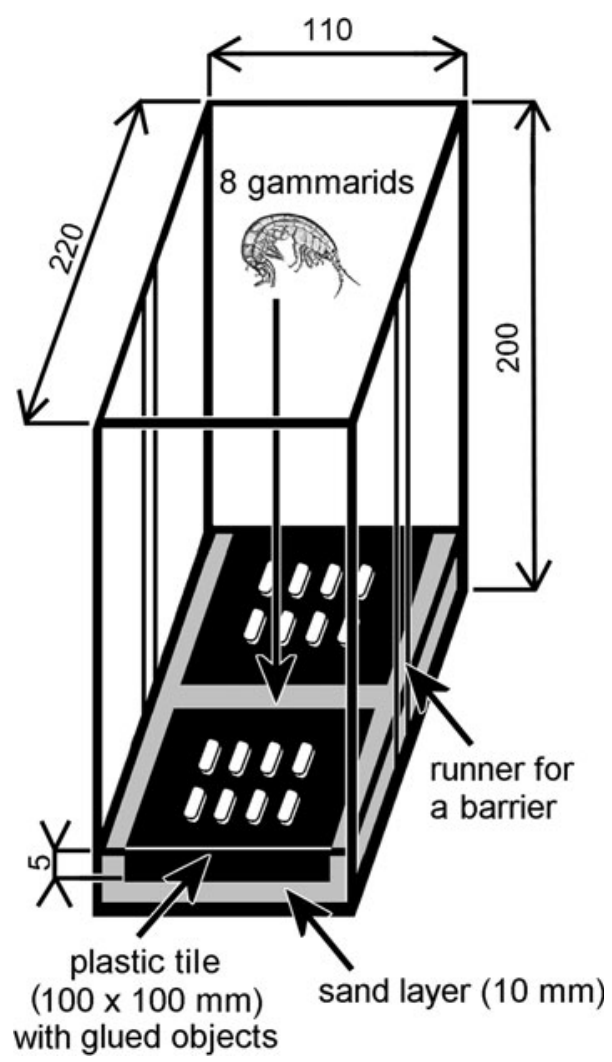

Fig. 1 Experimental tank. Dimensions are given in $\mathrm{mm}$ 
we carefully rinsed the prepared shells with running tap water for $1 \mathrm{~h}$ to get rid of its remnants.

After preparation, we kept all the shells (with and without periostracum) for at least 30 days in a 100-1 tank to allow for the biofilm development and vanishing of the residues of the silicone glue. Hereafter in this text we refer to such substratum as coated with "old biofilm". Then, we removed the biofilm from some shells by thorough sanding and scrubbing with a toothbrush in a solution of Sparkleen, a detergent designed for manual washing of glass (Fisher Scientific, Pittsburg, USA). It was applied with success by Wainman et al. (1996) to remove the biofilm from zebra mussels without harming them and leaving no residues after rinsing. We rinsed the cleaned shells with running water for $1 \mathrm{~h}$ to get rid of the detergent remnants. We cannot be sure that we removed the biofilm totally, including that from hardly accessible shell microcrevices (Zieritz et al., 2010), although we ran a preliminary test to validate the procedure (Table 1a). Nevertheless, the biofilm layer on cleaned surfaces was certainly weaker than on untreated objects. Altogether, we had four shell types: (\#1) with the intact periostracum and biofilm, (\#2) with the periostracum but without biofilm, (\#3) without the periostracum but with biofilm and (\#4) with both the periostracum and biofilm absent. Moreover, we exposed some of the cleaned shells (from group \#2) for a few days to obtain shells coated with younger biofilms, 1, 3, 4 or 5 days old (\#5).

We also used shells coated with fast-drying, waterresistant nail varnish (Astor $60 \mathrm{sec}$ ) to replace the natural shell surface with an artificial one without affecting the shape. Previous studies have shown that the varnish is neutral to gammarids, i.e. neither attracts nor repels them (Kobak \& Żytkowicz, 2007; Kobak et al., 2009). Like other substratum types, the varnished shells were either coated with the old biofilm (\#6) or devoid of it (\#7).

Yet another type of mussel shells used in our study were fresh shells (\#8), obtained by opening living mussels and careful removing their soft tissues with a pincette, scalpel and toothbrush. We used these shells in the experiments immediately after their preparation or after a short exposure ( 2 or 5 days) in aquarium water. To avoid the long air exposure necessary for silicone curing, in this case we used the methyl acrylic glue to join both shell valves. We only used it in this experiment as it is less convenient than the silicone, not filling empty spaces among joined surfaces.

We also used living mussels glued to the tiles by the ventral surface of one of their valves, so that they could open and produce byssus. One group of mussels was coated with their natural biofilm (\#9) whereas the other group (\#10) was devoid of this layer following the procedure described above. Due to the toxicity of sodium hypochlorite, we were unable to remove the periostracum from a living mussel. We did not feed the mussels during the tests and confirmed visually that they did not release faeces or pseudofaeces.

The next type of objects used in our study was mussel-sized stones purchased as aquarium substratum. We boiled the stones for disinfection and then kept some of them in aquarium water to allow for the development of the old biofilm (\#11). The second group of stones was never immersed in water (\#12). The third group included stones from which we cleaned the old biofilm (\#13) using the same procedure as that applied to the shells.

Altogether, we used 18 various substrata types, including 2 types of living mussels, 14 types of shells and 2 types of stones. We photographed 50 randomly selected objects from each type and measured them using ImageJ $1.40 \mathrm{~g}$ software (freeware by W. S. Rasband, U. S. National Institutes of Health, Bethesda, Maryland, USA, http://rsb.info.nih.gov/i). Their lengths (mean: $18.3 \mathrm{~mm}$, range 14.3-24.8 mm) did not differ significantly from one another (one-way ANOVA: $F_{11,588}=0.98, P=0.463$ ). Their widths differed from one another (ANOVA: $\left.F_{11,588}=6.80, P<0.001\right)$, but significant differences (Tukey test) occurred only between the stones (mean $12.7 \mathrm{~mm}$, range $9.2-16.1 \mathrm{~mm}$ ) and other objects (shells and mussels: $10.0 \mathrm{~mm}, 7.1-13.5 \mathrm{~mm}$ ). Because we never presented stones to gammarids together with shells or living mussels (see below), the dimensions of the objects forming different substrata in each experiment were always similar to each other. We also used ImageJ to measure the sizes of the studied gammarids.

\section{Experimental procedure}

Experimental tanks (Fig. 1) were filled with aerated tap water (left for at least $24 \mathrm{~h}$ before use) and contained a $1-\mathrm{cm}$ layer of sand at the bottom. We put 
Table 1 Substratum types used in various pairwise comparisons in the study

\begin{tabular}{|c|c|c|c|}
\hline & Substratum 1 & Substratum 2 & Purpose of the test \\
\hline $\mathrm{a}$ & $\begin{array}{l}\text { Stones never immersed in water } \\
\text { (no biofilm) (\#12) }\end{array}$ & Stones with old biofilm removed (\#13) & $\begin{array}{l}\text { To confirm the effectiveness of our biofilm } \\
\text { removal method; preliminary for (c), (d), (f), } \\
\text { (h), (i), (j), (l), (m) }\end{array}$ \\
\hline $\mathrm{b}$ & $\begin{array}{l}\text { Stones never immersed in water } \\
\text { (no biofilm) (\#12) }\end{array}$ & Stones with old biofilm (\#11) & $\begin{array}{l}\text { To check the effect of biofilm developing on } \\
\text { stones; preliminary for (a) }\end{array}$ \\
\hline $\mathrm{c}$ & $\begin{array}{l}\text { Old shells with periostracum and } \\
\text { with old biofilm (\#1) }\end{array}$ & $\begin{array}{l}\text { Old shells with periostracum and } \\
\text { without biofilm }(\# 2)\end{array}$ & $\begin{array}{l}\text { To check the effect of biofilm developing on } \\
\text { shells }\end{array}$ \\
\hline $\mathrm{d}$ & $\begin{array}{l}\text { Old shells without periostracum } \\
\text { and with old biofilm (\#3) }\end{array}$ & $\begin{array}{l}\text { Old shells without periostracum and } \\
\text { without biofilm (\#4) }\end{array}$ & $\begin{array}{l}\text { To check the effect of biofilm developing on } \\
\text { shells }\end{array}$ \\
\hline $\mathrm{e}$ & $\begin{array}{l}\text { Old shells with periostracum } \\
\text { and with old biofilm }(\# 1)\end{array}$ & $\begin{array}{l}\text { Old shells without periostracum and } \\
\text { with old biofilm (\#3) }\end{array}$ & To check the effect of periostracum cues \\
\hline $\mathrm{f}$ & $\begin{array}{l}\text { Old shells with periostracum } \\
\text { and without biofilm (\#2) }\end{array}$ & $\begin{array}{l}\text { Old shells without periostracum and } \\
\text { without biofilm }(\# 4)\end{array}$ & To check the effect of periostracum cues \\
\hline $\mathrm{g}$ & $\begin{array}{l}\text { Varnished shells with old } \\
\text { biofilm (\#6) }\end{array}$ & $\begin{array}{l}\text { Clean old shells without periostracum } \\
\text { and with old biofilm (\#3) }\end{array}$ & $\begin{array}{l}\text { To compare the effects of biofilms developing } \\
\text { various surfaces (shell vs. non-shell) }\end{array}$ \\
\hline $\mathrm{h}$ & $\begin{array}{l}\text { Varnished shells without } \\
\text { biofilm (\#7) }\end{array}$ & $\begin{array}{l}\text { Clean old shells without periostracum } \\
\text { and without biofilm (\#4) }\end{array}$ & $\begin{array}{l}\text { To check the effect of non-periostracum cues } \\
\text { associated with shells }\end{array}$ \\
\hline $\mathrm{i}$ & $\begin{array}{l}\text { Old shells with periostracum } \\
\text { and without biofilm }(\# 2)\end{array}$ & $\begin{array}{l}\text { Old shells with periostracum and with } \\
\text { 1-day biofilm (\#5) }\end{array}$ & To check the effect of biofilm age \\
\hline $\mathrm{j}$ & $\begin{array}{l}\text { Old shells with periostracum } \\
\text { and with old biofilm (\#1) }\end{array}$ & $\begin{array}{l}\text { Old shells with periostracum and with } \\
\text { 1-, 3-, 4- or 5-day biofilm (\#5) }\end{array}$ & To check the effect of biofilm age \\
\hline $\mathrm{k}$ & $\begin{array}{l}\text { Living mussels with old } \\
\text { biofilm }(\# 9)\end{array}$ & Old shells with old biofilm (\#1) & $\begin{array}{l}\text { To check the effect of living mussel cues; } \\
\text { preliminary for (l) and (m) }\end{array}$ \\
\hline 1 & $\begin{array}{l}\text { Living mussels without } \\
\text { biofilm (\#10) }\end{array}$ & Old shells without biofilm (\#2) & $\begin{array}{l}\text { To check the effect of living mussel cues } \\
\text { independent of the biofilm on their shells }\end{array}$ \\
\hline $\mathrm{m}$ & $\begin{array}{l}\text { Living mussels with old } \\
\text { biofilm (\#9) }\end{array}$ & Living mussels without biofilm (\#10) & $\begin{array}{l}\text { To check the effect of living mussel cues } \\
\text { associated with the biofilm on their shells }\end{array}$ \\
\hline $\mathrm{n}$ & $\begin{array}{l}\text { Living mussels with old } \\
\text { biofilm }(\# 9)\end{array}$ & $\begin{array}{l}\text { Fresh shells aged } 0,2 \text { or } 5 \text { days, with } \\
\text { old biofilm (\#8) }\end{array}$ & $\begin{array}{l}\text { To check the durability of the attractant } \\
\text { associated with living mussels }\end{array}$ \\
\hline
\end{tabular}

Bold text indicates a difference between both tested substrata. The descriptions in the table refer to the initial situation of each 20-h trial, i.e. a substratum described as "without biofilm" actually had a 1-day biofilm on its surface at the end of the test and so on. "Old biofilm" was a biofilm developing for ca. 30 days or more. Old shells were used several months after the mussels' death. Fresh shells were taken immediately after the mussels' death. Numbers prefixed by "\#” refer to particular substratum descriptions in the text

two tiles with different objects on the tank bottom, adjacent to its shorter walls and immersed them in the sand so that their surfaces were at the level of the sand surface. The position of different substrata relative to the laboratory room varied in various replicates. We released 8 gammarids in the middle of the tank. The resulting density of ca. 330 ind. $\mathrm{m}^{-2}$, corresponds to intermediate gammarid densities in the field (Felten et al., 2008; Żytkowicz et al., 2008). After 20 h, we divided the tank into halves with a glass barrier and determined the gammarid location.

Altogether, we ran 19 pairwise tests with different pairs of substrata, each replicated $10-15$ times. We ran more replicates if the initial results did not allow to draw firm conclusions on the gammarid selectivity in a given case, e.g. when the results were on the border of statistical significance $(P$ close to 0.05$)$ or inconsistent with our working hypotheses. All pairwise combinations of object types used in our study, as well as the questions we intended to answer by conducting particular tests, are listed in Table 1.

We monitored water quality during the experiments with a multimeter Multi340i (WTW GmbH, Weilheim, Germany). Mean temperature was $19.9^{\circ} \mathrm{C}$ (range 19.6-20.5 $\left.{ }^{\circ} \mathrm{C}\right)$, oxygen concentration $6.7 \mathrm{mg} \mathrm{l}^{-1}$ (5.9-7.2 $\mathrm{mg} \mathrm{l}^{-1}$ ), oxygen saturation $74 \%(67-82 \%)$, pH $8.0(7.8-8.1)$ and conductivity $500 \mu \mathrm{S} \mathrm{cm}(492$ $-532 \mu \mathrm{S} \mathrm{cm})$. We conducted our experiments in 
darkness as some substrata differed from one another in colour (e.g. whitish shells devoid of periostracum, red varnished shells, etc.), which could potentially affect gammarid choice.

Preliminary test: validation of the biofilm removal method

We checked if gammarids would discriminate stones cleaned of biofilm from those that had never been biofilmed (Table 1a). The preference for or avoidance of the former would indicate the imperfection of the biofilm removal or the repelling effect of the detergent remnants, respectively. No discrimination by gammarids would justify the use of our biofilm removal procedure in the further tests. Before this experiment, we made sure that the biofilm developing on stones did affect gammarids, by offering them a choice between clean (never biofilmed) and biofilmed stones (Table 1b).

Responses of gammarids to empty mussel shells

To study the effect of the biofilm coating empty shells, we exposed gammarids to biofilmed and cleaned shells, both either coated by or devoid of the periostracum (Table 1c, d). To examine the effect of the periostracum-associated cues on gammarids, we offered them shells with and without the periostracum, both either biofilmed or cleaned (Table 1e, f). Because the periostracum turned out to be an attractant for gammarids (see "Results"), we checked if its removal totally cancels or only weakens the attracting properties of shells. We exposed gammarids to shells devoid of their periostracum and varnished shells (both either biofilmed or cleaned), the latter having a completely artificial surface (Table $1 \mathrm{~g}, \mathrm{~h}$ ).

Responses of gammarids to biofilms of various ages

To allow for the fact that biofilmed shells could be preferred by gammarids (see "Results"), we also examined the effect of biofilm age. We designed two series of tests. Firstly, we checked whether gammarids discriminated between shells devoid of biofilm and shells coated with biofilms of increasing age (Table 1i). We planned to continue this series till obtaining the first significant difference, to find the age at which the biofilm starts to act as an attractant. In the second series, we estimated the age at which the attractive properties of the biofilm became fully developed by exposing gammarids to shells coated with the old biofilm and shells coated by biofilms of increasing age (Table $1 \mathrm{j}$ ) until gammarid preferences disappeared.

Responses of gammarids to living mussels

To check the cues associated with living mussels, we presented them to gammarids together with empty shells, with both types of objects biofilmed or cleaned (Table 1k, 1). We also exposed gammarids in the presence of biofilmed and cleaned living mussels to check for the effect of the biofilm developing on living bivalves (Table $1 \mathrm{~m}$ ).

To allow for the fact that living mussels would be preferred over shells (see "Results"), we intended to check the attractant durability by offering gammarids a choice between living mussels and fresh shells obtained immediately after the mussels' death or a few days later (after a 2- to 5-day exposure in water). We assumed that the gammarid preference for the living mussels would appear as the attractant would expire from the shells (Table 1n).

\section{Statistical analysis}

If gammarids did not discriminate between the two substratum types offered to them, they should be randomly distributed in the tank, with $50 \%$ of individuals in each zone. For each pair of substratum types, we compared the mean percentage of animals found in one of the tank zones with a theoretical value of $50 \%$ using a one-sample $t$ test. These tests allowed to determine whether gammarids discriminated between both substrata offered to them in a given treatment. Moreover, to compare gammarid behaviour (i.e. percentages of individuals occupying a given substratum in the particular treatment) among various treatments, we conducted $t$ tests for independent samples or one-way ANOVAs (depending on the number of compared groups) for: (1) responses to cleaned and biofilmed stones in the presence of stones never coated with biofilm (Table 1a, b); (2) responses to the biofilm on the shells with and without the periostracum (Table 1c, d); (3) responses to the periostracum on shells with and without biofilm (Table 1e-f); (4) responses to the varnished shells with and without the biofilm (Table $1 \mathrm{~g}, \mathrm{~h}$ ); (5) responses to the biofilms of various 
ages (Table 1j); (6) responses to the living mussels with and without the biofilm (Table $1 \mathrm{k}, 1$ ) and (7) responses to the fresh shells at various times after the mussel's death (Table 1n). We did not transform the data as they did not depart from the normality assumption (Shapiro-Wilk tests).

\section{Results}

According to our expectations, in the preliminary tests conducted to validate our method of biofilm removal, the gammarids preferred biofilmed stones over bare stones (Fig. 2a). Their selectivity disappeared after cleaning the biofilmed stones (Fig. 2b). Gammarid responses to biofilmed and cleaned stones differed significantly from each other ( $t$ test: $t_{23}=2.68$, $P=0.013$ ), confirming the effectiveness of our method and justifying its use in the other experiments.
The gammarids were strongly attracted to the biofilm coating zebra mussel shells (Fig. 2c, d), irrespective of the presence or absence of their periostracum ( $t$ test: $\left.t_{18}=0.91, P=0.375\right)$. They did not differentiate between biofilmed shells covered by periostracum or not (Fig. 2e). A positive effect of the periostracum shell layer on gammarid habitat selection also occurred, though only when the shells were devoid of biofilm (Fig. 2f), resulting in a significant difference in mussel responses to the periostracum between biofilmed and clean shells ( $t$ test: $t_{23}=2.38, P=0.026$ ). The gammarids responded similarly to shells devoid of periostracum and to those coated with varnish (Fig. $2 \mathrm{~g}, \mathrm{~h}$ ), whether biofilmed or not $\left(t\right.$ test: $t_{18}=0.25, P=0.808$ ).

The gammarids were able to detect a biofilm developing for just 1 day (Fig. 3a). Therefore, we did not continue this series of tests with the older biofilms. Furthermore, the old biofilm ( $>30$-day old) was a

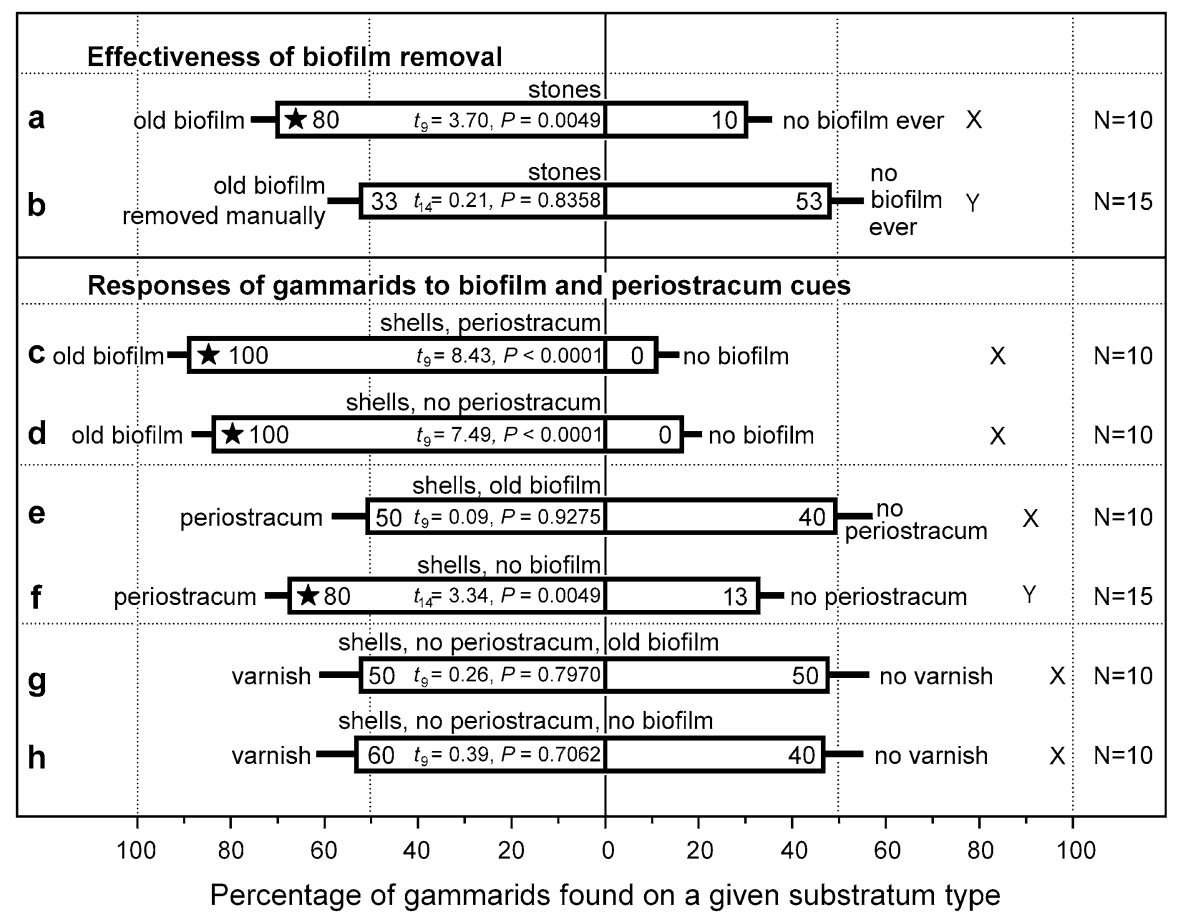

Fig. 2 Responses of gammarids to empty mussel shells. The features shared by both tested substrata are shown above the bars, whereas those differentiating them appear on the sides. The bars show the total percentages of gammarids occupying particular substrata. The values near the bar tips show the percentages of cases (replicates) in which the given substratum type was selected by the greater number of gammarids than the other type. The results of the corresponding one-sample $t$ tests examining the departures of the gammarid distributions from a random pattern (50: 50\%) are shown on the bars, with significant differences marked by asterisks. Gammarid behaviour did not vary significantly ( $t$ test or ANOVA) among treatments labelled with the same letter (XY) on the right within a given set of treatments. The error bars show standard errors of means. $N$ values on the right are the numbers of replicates in the particular experiments 
stronger attractant than that developing for 3 days or less (Fig. 3b, c). The effect of the 4- and 5-day-old biofilms was similar to that of the old biofilm (Fig. 3d, e). Consequently, there was a significant difference in the selectivity of gammarids exposed to the biofilms of various ages (ANOVA: $F_{3,36}=6.97, P=0.001$ ), with gammarid responses to the 1- to 3-day-old biofilms differing significantly from those elicited by 4- to 5-day-old biofilms (Tukey post hoc test).

Living mussels were a stronger attractant than old empty shells (Fig. 4a, b). The gammarids preferred living mussels over shells independent of the presence or absence of the biofilm ( $t$ test: $t_{18}=1.17$, $P=0.256)$. In contrast to their responses to empty shells and stones, they did not discriminate between biofilmed and clean living mussels (Fig. 4c).

The gammarid responses to fresh mussel shells were different than those induced by old shells, used a few months after the mussels' death. The gammarids did not distinguish between living mussels and fresh mussel shells obtained immediately after the animals' death (Fig. 4d), but, contrary to our expectations, they clearly preferred fresh mussel shells 2-5 days after their preparation, rather than living mussels (Fig. 4e, f). Gammarid responses to fresh shells at various times after the mussel's death differed significantly from one another (ANOVA: $F_{2,42}=5.48, P=0.008$ ). The only significant difference (revealed by the Tukey post hoc test) in gammarid behaviour was observed between the individuals exposed to the shells obtained immediately after a mussel's death (no selectivity) and those offered the 5-day-old shells (the strongest selectivity). The behaviour of gammarids in the presence of the 3-day-old fresh shells did not differ significantly from any other treatments. This shows that shell properties changed gradually after a mussel death.

\section{Discussion}

The gammarids selected (in order of decreasing preference): (1) fresh mussel shells, (2) living mussels, (3) old shells with intact surface, (4) old shells without biofilm and (5) old shells with neither periostracum nor biofilm. Thus, cues associated with both the biofilm and periostracum were detected and used by gammarids, though their relative strengths and interrelationships appeared quite complex.

Gammarid responses to biofilm cues

Biofilm was an important cue affecting gammarid habitat selection. They responded positively to the biofilms developing on stones and shells, but did not discriminate among biofilmed shells differing in their surface properties, ranging from natural surfaces, through those devoid of periostracum, to artificial varnish coatings. Thus, the presence of biofilm affects gammarids, but its quality, associated with particular surface types, does not. Therefore, the biofilm quality could not be responsible for the gammarid preferences for zebra mussel shells, observed by Kobak \& Żytkowicz (2007) and Kobak et al. (2009).

The presence and quality of biofilm is extremely important for aquatic organisms. Bacteria, microalgae and protozoans are the first colonizers of any objects deployed in water, forming a coating layer and determining the conditions for further settlers (Maki
Fig. 3 Responses of gammarids to biofilms of various ages. See Fig. 2 for the explanations of symbols and descriptions

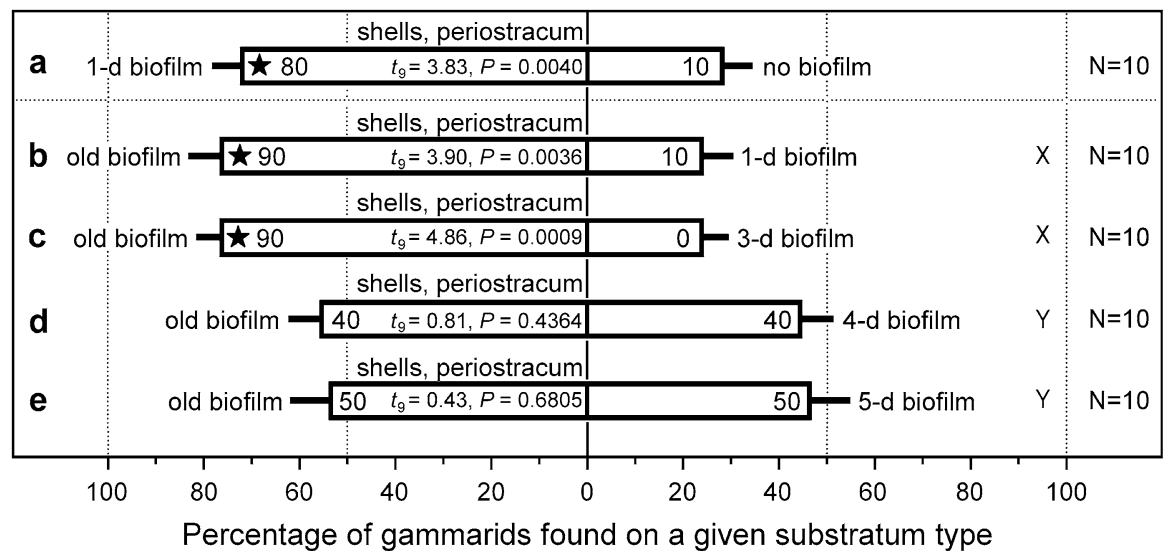


Fig. 4 Responses of gammarids to living mussels. See Fig. 2 for the explanations of symbols and descriptions

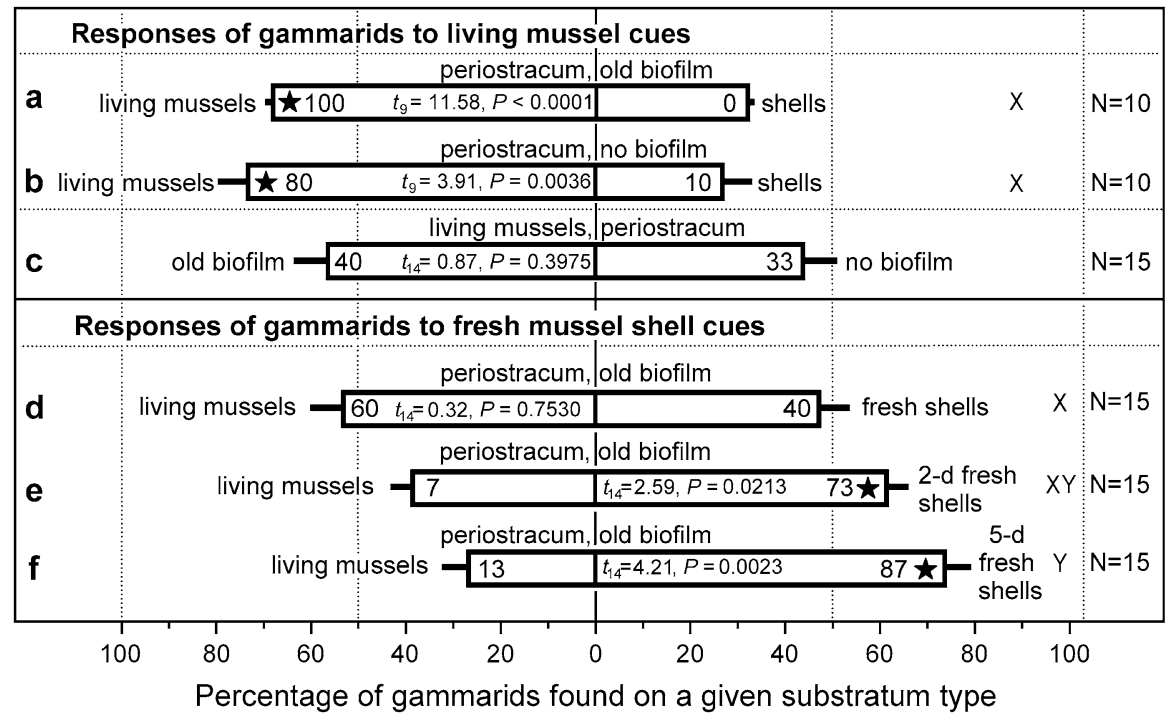

Gammarid responses to periostracum cues

et al., 1990). The presence of biofilm guarantees that a submerged structure has remained in water for some time (an indication of substratum stability) and provides food for some taxa (Berezina, 2007). Therefore, animals usually prefer biofilmed surfaces (Maki et al., 1990; Tamburri et al., 1992; Wainman et al., 1996; Chen et al., 2007), though an inhibitory impact of certain biofilms on macrofoulers has also been observed (Maki et al., 1990; Kavouras \& Maki, 2004). Biofilms differing in their taxonomic composition and activity are likely to develop on various substrata. Particularly zebra mussels can modify the local microbial community (Lohner et al., 2007). Furthermore, even the same bacteria can have different properties depending on their substratum quality (Maki et al., 1990). Nevertheless, we did not observe any differences in the impact of the biofilms developing on various substrata on the gammarid habitat choice.

Even very young biofilms attracted gammarids. Moreover, gammarid responses to quite young biofilms (4-day-old only) were similar to their reactions to old biofilms. This is consistent with the fact that biofilms develop very quickly on submerged surfaces. Similarly, reattaching zebra mussels responded positively to 48-h-old biofilms (Kavouras \& Maki, 2003) and barnacle larvae detected settlement stimuli released by a 1-day-old biofilm (Chen et al., 2007). Thus, submerged objects very quickly become suitable for the colonization by epifauna, both sedentary (mussels, barnacles) and mobile (gammarids).
The gammarids detected some cues associated with the periostracum of empty shells, preferring the intact shells over those devoid of the periostracum. However, this effect disappeared in the presence of biofilm. Thus, the biofilm-associated cue seems to be stronger. Gammarids can discriminate between shells with intact and varnished (i.e. artificial) surfaces, preferring the former (Kobak \& Żytkowicz, 2007; Kobak et al., 2009), but they did not distinguish between varnished shells and those devoid of periostracum in our study, showing that the attractant was completely eliminated with the periostracum removal.

Periostracum is the outermost layer of the molluscan shell, consisting of quinone-tanned protein, the conchiolin. It shapes the growth of the deeper calcareous layers and protects them from corrosion (Checa, 2000; Zieritz et al., 2010). Periostracum may also protect from drilling gastropod predators (Stone, 1998) and affect the site selection behaviour of other organisms, such as larvae of the eastern oyster Crassostrea virginica (Gmelin, 1791) settling in response to the conspecific periostracum (Crisp, 1967; Tamburri et al., 1992), or barnacle larvae avoiding recruitment on the shells of Mytilus sp. and Perna sp. (Bers et al. 2006a, b, 2010). Gammarids use mussel beds differently than the above-mentioned sedentary organisms, as they move freely and hide among shells rather than occupy permanent adhesion 
sites. Anyway, they also use periostracum-associated cues for their habitat detection.

Gammarid responses to living mussels

Living mussels were preferred over old shells, regardless of the presence or absence of the biofilm. This result differs from that obtained for empty shells, where the presence of the biofilm obscured the effect of the periostracum cue. As the gammarids did not respond to mussel activity, viz. valve movements and byssus production (Kobak \& Żytkowicz, 2007; Kobak et al., 2009) and did not discriminate between biofilmed and cleaned living mussels (this study), we can conclude that the specific cue must be associated with the periostracum.

The most surprising result of our study was the preference of gammarids to fresh shells over living mussels. Thus, the attractant seems to be associated with the shell of a living or recently deceased mussel and not with any secretions of a living individual. Alternatively, the gammarids could be attracted to the decomposing remnants of the soft mussel tissues (acting as feeding attractants) in the fresh shells. However, after 5 days of exposure in water these remnants should have been gone while the positive effect of shells did not expire. The avoidance of the waterborne effluents of living zebra mussels by Gammarus roeseli Gervais, 1835 and D. villosus was observed by Gergs \& Rothhaupt (2008b). Perhaps, the high mussel density may negatively affect gammarids by generating oxygen deficiencies and/or waste accumulation (Gergs \& Rothhaupt, 2008b). Therefore, gammarids might be attracted by the habitats with lower densities of living zebra mussels, but still containing detectable cues.

Responses of macroinvertebrates to mussel beds

Mussel bed habitats are likely to increase the survival of their inhabitants, including gammarids. The positive effect of mussels upon gammarids was observed in several studies. Chaetogammarus ischnus and Gammarus fasciatus Say, 1818 survived better in mussel colonies when exposed to fish predation (Gonzalez \& Burkart 2004) and D. villosus grew faster on mussel pseudofaeces than on plant material (Gergs \& Rothhaupt 2008a).
Active movement towards zebra mussels was also observed in other invertebrates. A snail Physella heterostropha (Say, 1871) selected empty mussel shells in the presence of predator kairomones (Stewart et al., 1999) and a mayfly Hexagenia sp. occupied bivalve clusters hiding from predatory fish (DeVanna et al., 2011). Furthermore, some benthivores, such as Ponto-Caspian neogobiid fish were found to avoid shell habitats (Kakareko, 2011), which increases the role of mussel beds as anti-predator shelters. These data, together with our present findings, confirm the high importance of zebra mussels as habitat engineers, as well as the potential of other organisms to adapt to the structures formed by mussels and utilize them efficiently. Thus, increased zoobenthos abundances within mussel colonies may result not only from the better survival in suitable conditions (food, shelters) offered by bivalves, but also from the active preferences of certain organisms for mussel beds.

Zebra mussels affect positively not only other aliens, but also many local species (Wolnomiejski, 1970; Kestrup \& Ricciardi, 2009; DeVanna et al., 2011). However, their presence may be much more crucial for Ponto-Caspian invaders, as mussels transform novel, likely inhospitable environments into habitats similar to those occurring in their native regions. On the other hand, native species are welladapted to the habitats in which they had evolved for a long time, and mussel-driven condition changes may be less essential for them, even if they can also benefit from their presence. Thus, dreissenid colonies may promote the spread of Ponto-Caspian gammarids and the preferences of these species for mussel beds are likely to facilitate this phenomenon.

Acknowledgments We are grateful to Marcin Budrewicz, a SCUBA diver who helped us collect mussels and gammarids for our experiments. Our research was supported by a Grant of the Polish Ministry of Science and Higher Education No. N N304 393038 .

Open Access This article is distributed under the terms of the Creative Commons Attribution License which permits any use, distribution, and reproduction in any medium, provided the original author(s) and the source are credited.

\section{References}

Arbaciauskas, K., 2002. Ponto-Caspian amphipods and mysids in the inland waters of Lithuania: History of introduction, current distribution and relations with native 
malacostracans. In Leppäkoski, E., S. Gollasch \& S. Olenin (eds), Invasive Aquatic Species of Europe: Distribution, Impacts and Management. Kluwer Academic Publishers, Boston: 104-115.

Berezina, N., 2007. Invasions of alien amphipods (Amphipoda: Gammaridea) in aquatic ecosystems of North-Western Russia: pathways and consequences. Hydrobiologia 590: 15-29.

Berezina, N. A. \& V. E. Panov, 2003. Establishment of new gammarid species in the eastern Gulf of Finland (Baltic Sea) and their effects on littoral communities. Proceedings of Estonian Academy of Sciences, Biology, Ecology 52: 284-304.

Bers, A. V., G. S. Prendergast, C. M. Zürn, L. Hansson, R. M. Head \& J. C. Thomason, 2006a. A comparative study of the anti-settlement properties of mytilid shells. Biological Letters 2: 88-91.

Bers, A. V., F. D'Souza, J. W. Klijnstra, P. R. Willemsen \& M. Wahl, 2006b. Chemical defence in mussels: antifouling effect of crude extracts of the periostracum of the blue mussel Mytilus edulis. Biofouling 22: 251-259.

Bers, A. V., E. R. Diaz, B. A. P. da Gama, F. Vieira-Silva, S. Dobretsov, N. Valdivia, M. Thiel, A. J. Scardino, C. D. McQuaid, H. E. Sudgen, J. C. Thomason \& M. Wahl, 2010. Relevance of mytilid shell microtopographies for fouling defence-a global comparison. Biofouling 26: 367-377.

bij de Vaate, A., K. Jażdżewski, H. Ketelaars, S. Gollasch \& G. van der Velde, 2002. Geographical patterns in range extension of macroinvertebrate Ponto-Caspian species in Europe. Canadian Journal of Fisheries and Aquatic Sciences 59: 1159-1174.

Boets, P., K. Lock, M. Messiaen \& P. L. M. Goethals, 2010. Combining data-driven methods and lab studies to analyse the ecology of Dikerogammarus villosus. Ecological Informatics 5: 133-139.

Botts, P. S., B. A. Patterson \& D. W. Schloesser, 1996. Zebra mussel effects on benthic macroinvertebrates: physical or biotic? Journal of the North American Benthological Society 15: 179-184.

Checa, A., 2000. A new model for periostracum and shell formation in Unionidae (Bivalvia, Mollusca). Tissue and Cell 32: 405-416.

Chen, P. H., Y. H. Chen \& I. M. Chen, 2007. Effect of biofilm age and type on settlement of cyprids of the barnacle, Fistulobalanus albicostatus Pilsbry (Thoracica: Balanidae). Zoological Studies 46: 521-528.

Costello, M. J. \& A. A. Myers, 1996. Turnover of transient species as a contributor to the richness of a stable amphipod (Crustacea) fauna in a sea inlet. Journal of Experimental Marine Biology and Ecology 202: 49-62.

Crisp, D. J., 1967. Chemical factors inducing settlement in Crassostrea virginica (Gmelin). Journal of Animal Ecology 36: 329-335.

Czarnecka, M., J. Kobak \& R. Wiśniewski, 2010. Preferences of juveniles and adults of the invasive Ponto-Caspian amphipod Pontogammarus robustoides for various species of macrophytes and artificial substrata. Hydrobiologia 655: 79-88.

DeVanna, K. M., P. M. Armenio, C. A. Barrett \& C. M. Mayer, 2011. Invasive ecosystem engineers on soft sediment change the habitat preferences of native mayflies and their availability to predators. Freshwater Biology 56: 2448-2458.
Devin, S. \& J. N. Beisel, 2007. Biological and ecological characteristics of invasive species: a gammarid study. Biological Invasions 9: 13-24.

Devin, S., C. Piscart, J. N. Beisel \& J. C. Moreteau, 2003. Ecological traits of the amphipod invader Dikerogammarus villosus on a mesohabitat scale. Archiv für Hydrobiologie 158: 43-56.

Felten, V., S. Dolédec \& B. Statzner, 2008. Coexistence of an invasive and a native gammarid across an experimental flow gradient: flow-refuge use, mortality and leaf-litter decay. Fundamental and Applied Limnology 172: 37-48.

Gergs, R. \& K. O. Rothhaupt, 2008a. Feeding rates, assimilation efficiencies and growth of two amphipod species on biodeposited material from zebra mussels. Freshwater Biology 53: 2494-2503.

Gergs, R. \& K. O. Rothhaupt, 2008b. Effects of zebra mussels on a native amphipod and the invasive Dikerogammarus villosus: the influence of biodeposition and structural complexity. Journal of the North American Benthological Society 27: 541-548.

Gonzalez, M. \& G. Burkart, 2004. Effects of food type, habitat and fish predation on the relative abundance of two amphipod species, Gammarus fasciatus and Echinogammarus ischnus. Journal of Great Lakes Research 30: 100-113.

Grabowski, M., K. Bạcela \& A. Konopacka, 2007. How to be an invasive gammarid (Amphipoda: Gammaroidea)—comparison of life history traits. Hydrobiologia 590: 75-84.

Jażdżewski, K., A. Konopacka \& M. Grabowski, 2002. Four Ponto-Caspian and one American gammarid species (Crustacea, Amphipoda) recently invading Polish waters. Contributions to Zoology 71: 115-122.

Kakareko, T., 2011. Wpływ wybranych czynników na rozmieszczenie i preferencje siedliskowe babki łysej (Neogobius gymnotrachelus Kessler, 1857) i babki szczupłej (Neogobius fluviatilis Pallas, 1811), obcych gatunków ryb w Polsce. [Impact of selected factors on the distribution and habitat preferences of two non-native fish species in Poland: racer goby Neogobius gymnotrachelus and monkey goby Neogobius fluviatilis]. Wydawnictwo Naukowe UMK, Toruń, Poland.

Karatayev, A. Y., L. E. Burlakova \& D. K. Padilla, 2002. Impacts of zebra mussels on aquatic communities and their role as ecosystem engineers. In Leppäkoski, E., S. Gollasch \& S. Olenin (eds), Invasive Aquatic Species of Europe: Distribution Impacts and Management. Kluwer Academic Publishers, Boston: 433-446.

Kavouras, J. H. \& J. S. Maki, 2003. The effects of natural biofilms on the reattachment of young adult zebra mussels to artificial substrata. Biofouling 19: 247-256.

Kavouras, J. H. \& J. S. Maki, 2004. Inhibition of the reattachment of young adult zebra mussels by single-species biofilms and associated exopolymers. Journal of Applied Microbiology 97: 1236-1246.

Kestrup, A. \& A. Ricciardi, 2009. Are interactions among Ponto-Caspian invaders driving amphipod species replacement in the St. Lawrence River? Journal of Great Lakes Research 35: 392-398.

Kley, A. \& G. Maier, 2006. Reproductive characteristics of invasive gammarids in the Rhine-Main-Danube catchment, South Germany. Limnologica 36: 79-90. 
Kobak, J., 2005. Recruitment and distribution of Dreissena polymorpha (Bivalvia) on substrates of different shape and orientation. International Review of Hydrobiology 90: 159-170.

Kobak, J. \& J. Żytkowicz, 2007. Preferences of invasive Ponto-Caspian and native European gammarids for zebra mussel (Dreissena polymorpha, Bivalvia) shell habitat. Hydrobiologia 589: 43-54.

Kobak, J., T. Kakareko, M. Poznańska \& J. Żbikowski, 2009. Preferences of the Ponto-Caspian amphipod Dikerogammarus haemobaphes for living zebra mussels. Journal of Zoology 279: 229-235.

Kobak, J., M. Poznańska \& T. Kakareko, 2012. Behavioural changes of zebra mussel Dreissena polymorpha (Bivalvia) induced by Ponto-Caspian gammarids. Biological Invasions. doi:10.1007/s10530-012-0197-x.

Konopacka, A., 2004. Inwazyjne skorupiaki obunogie (Crustacea, Amphipoda) w wodach Polski [Invasive amphipods (Crustacea, Amphipoda) in Polish waters]. Przegląd Zoologiczny 48: 141-162.

Lohner, R. N., V. Sigler, C. M. Mayer \& C. Balogh, 2007. A comparison of the benthic bacterial communities within and surrounding Dreissena clusters in lakes. Microbial Ecology 54: 469-477.

MacNeil, C., J. T. A. Dick \& R. W. Elwood, 1997. The trophic ecology of freshwater Gammarus spp. (Crustacea: Amphipoda): problems and perspectives concerning the functional feeding group concept. Biological Reviews 72: 349-364.

MacNeil, C., J. T. A. Dick, D. Platvoet \& M. Briffa, 2011. Direct and indirect effects of species displacements: an invading freshwater amphipod can disrupt leaf-litter processing and shredder efficiency. Journal of the North American Benthological Society 30: 38-48.

Maki, J. S., D. Rittschof, M. Q. Samuelsson, U. Szewzyk, A. B. Yule, S. Kjelleberg, J. D. Costlow \& R. Mitchell, 1990. Effect of marine bacteria and their exopolymers on the attachment of barnacle cypris larvae. Bulletin of Marine Science 46: 499-511.

Martin, I. D., G. L. Mackie \& M. Baker, 1992. Acute toxicity and pulse-dosed delayed mortality at 12 and $22^{\circ} \mathrm{C}$ with sodium hypochlorite, Bulab 6002 and hydrogen peroxide on the biofouling mollusk, Dreissena polymorpha. Archives of Environmental Contamination and Toxicology 24: 381-389.

Platvoet, D., G. van der Velde, J. T. A. Dick \& S. Q. Li, 2009. Flexible omnivory in Dikerogammarus villosus (Sowinsky, 1894) (Amphipoda)—amphipod pilot species project (AMPIS) Report 5. Crustaceana 82: 703-720.

Ricciardi, A., 2001. Facilitative interactions among aquatic invaders: is an "invasional meltdown" occurring in the Great Lakes? Canadian Journal of Fisheries and Aquatic Sciences 58: 2513-2525.

Ricciardi, A., F. G. Whoriskey \& J. B. Rasmussen, 1997. The role of the zebra mussel (Dreissena polymorpha) in structuring macroinvertebrate communities on hard substrata. Canadian Journal of Fisheries and Aquatic Sciences 54: 2596-2608.

Simberloff, D. \& B. Von Holle, 1999. Positive interactions of nonindigenous species: invasional meltdown? Biological Invasions 1: 21-32.

Stewart, T. W., J. C. Gafford, J. G. Miner \& R. L. Lowe, 1999. Dreissena-shell habitat and antipredator behavior: combined effects on survivorship of snails co-occurring with molluscivorous fish. Journal of the North American Benthological Society 18: 274-283.

Stone, H. M. I., 1998. On predator deterrence by pronounced shell ornament in epifaunal bivalves. Paleontology 41: 1051-1068.

Tamburri, M. N., R. K. Zimmer-Faust \& M. L. Tamplin, 1992. Natural sources and properties of chemical inducers mediating settlement of oyster larvae: a re-examination. Biological Bulletin 183: 327-338.

Van Overdijk, C. D. A., I. A. Grigorovich, T. Mabee, W. J. Ray, J. H. Ciborowski \& H. J. MacIsaac, 2003. Microhabitat selection by invasive amphipod Echinogammarus ischnus and native Gammarus fasciatus in laboratory experiments and in Lake Erie. Freshwater Biology 48: 567-578.

van Riel, M. C., E. P. Healy, G. van der Velde \& A. bij de Vaate, 2007. Interference competition among native and invader amphipods. Acta Oecologica 31: 282-289.

Wainman, B. C., S. S. Hincks, N. K. Kaushik \& G. L. Mackie, 1996. Biofilm and substrate preference in the dreissenid larvae of Lake Erie. Canadian Journal of Fisheries and Aquatic Sciences 53: 134-140.

Wawrzyniak-Wydrowska, B. \& P. Gruszka, 2005. Population dynamics of alien gammarid species in the River Odra estuary. Hydrobiologia 539: 13-25.

Werner, S. \& K.-O. Rothhaupt, 2008. Effects of the invasive Asian clam Corbicula fluminea on benthic macroinvertebrate taxa in laboratory experiments. Fundamental and Applied Limnology 173: 145-152.

Wolnomiejski, N., 1970. The effects of Dreissena polymorpha Pall. aggregation on the differentiation of the benthonic macrofauna. Acta Universitatis Nicolai Copernici, Limnological Papers 5: 31-39.

Zieritz, A., A. G. Checa, D. C. Aldridge \& E. M. Harper, 2010. Variability, function and phylogenetic significance of periostracal microprojections in unionoid bivalves (Mollusca). Journal of Zoological Systematics and Evolutionary Research 49: 6-15.

Żytkowicz, J., J. Kobak, T. Kakareko \& A. Kentzer, 2008. Species composition and distribution of invasive PontoCaspian amphipods in the off-channel microhabitats of a temperate, lowland dam reservoir. International Review of Hydrobiology 93: 62-72. 